www.jmscr.igmpublication.org

Index Copernicus Value: 79.54

ISSN (e)-2347-176x ISSN (p) 2455-0450

crossref DOI: https://dx.doi.org/10.18535/jmscr/v7i6.84

\title{
Orbital and Ocular Complications of External Beam Radiation Therapy (EBRT) for Retinoblastoma (Rb)
}

\author{
Authors \\ Dr Nibedita Acharya ${ }^{1 *}$, Dr Usha Vasu ${ }^{2}$
}

St. Johns Medical College and Hospital and Kidwai Institute of Oncology, Bangalore

*Corresponding Author

Dr Nibedita Acharya

Professor, Department of Ophthalmology, BGS Global Institute of Medical Sciences,

\#67, BGS Health and Education City, Uttarahalli road, Kengeri, Bangalore - 560060, India

\begin{abstract}
Introduction: External beam radiotherapy $(E B R T)$ was the preferred form of management of moderately advanced retinoblastoma in late 1900s. But because of its serious side-effects, and also the availability of other safer treatment options EBRT is being used less often now.

Aim: The aim of this study is to highlight the Orbital and Ocular Complications of External Beam Radiation Therapy, their recognition and prevention.

Materials and Methods: Retrospective data analysis of retinoblastoma patients who presented to our institution over past 14 years were done. The case records of patients with minimum follow up of 6 months and maximum follow up of 10 years were included in the study. The stage of retinoblastoma and type of external beam radiotherapy given to them was documented. The complications observed after external beam radiotherapy treatment were noted down. Details of the treatment given to these patients were documented.

Results: Total 46 patients were included in the study. Of this 29 children received only Unilateral EBRT (Group I) while 17 received bilateral EBRT (Group II). Contracted socket was the most common complication seen in both the groups - 17 in group I and 11 in group II. Second common complication was ocular surface abnormalities which kept on recurring in spite of treatment. Other complications observed were facial hypoplasia, radiation retinopathy, orbital cellulitis, cataract etc.

Conclusion: Since external beam radiotherapy is still used to treat the late stage of Retinoblastoma in poor Indian patients, awareness of complications of EBRT is worthwhile. Keeping the side effects in mind, it is always preferable to advise other modalities of treatment for retinoblastoma instead of EBRT.

Keywords: External beam radiotherapy, Retinoblastoma, contracted socket.
\end{abstract}

\section{Introduction}

External Beam Radiotherapy was introduced in 1903 as a conservative or eye-preserving therapy for retinoblastoma ${ }^{1}$. This treatment uses high energy x-rays or particles to kill cancer cells. Compared with surgery, it has the advantage of possibly saving vision in the eye. External Beam Radiotherapy (EBRT) was the treatment of choice for intra-ocular retinoblastoma $(\mathrm{Rb})$ for much of the 20th century. But EBRT can damage nearby normal body tissues. This might eventually lead to cataract formation, radiation retinopathy, which 
could reduce vision ${ }^{[1,2]}$. Radiation can also slow the growth of bones and other tissues near the eye and radiation increases the risk of developing second tumours in the body ${ }^{[3,4]}$. Because of the growing concern about the serious side-effects of EBRT, and also the availability of Brachytherapy and other adjuvant methods of treatment for $\mathrm{Rb}$ : EBRT is now considered "to be avoided" mode of therapy. But in India, specifically in Karnataka, availability of Brachytherapy and other modes of treatment is limited and EBRT along with Chemotherapy still remains as one of the treatment choices, especially to poor patients, who cannot afford other modes of treatment.

\section{Aim:}

The aim of this study is to analyze the data of patients with Retinoblastoma who were given EBRT to provide insight into the complications of EBRT and how to recognize and prevent it.

\section{Materials and Methods}

This retrospective data analysis was done on available data in our institution from 2003 to 2016. The demographic details of all the retinoblastoma patients and the stage of the disease at presentation were noted. EBRT was used for treating patients with multifocal RB and those with tumors close to the macular or optic nerve with preserved vision. EBRT was also given to large tumors, those with vitreous seeding that did not respond to systemic chemotherapy and to empty sockets after enucleation. The dose and duration of external beam radiotherapy regimen for each patient was noted (Standard EBRT regimen used to be: Average total dosage of 48005000 cGy, divided over a period of 3 weeks duration. Children were given radiation for 5 days a week, with fractions of 180-200 cGy per day. If regression was poor, 10 days more of therapy with a maximal dose of $6000 \mathrm{cGy}$ was given. All the children were sedated while giving EBRT, so that they remain immobile during the course of the procedure. During each session, the child had to lie on a special table while radiation was delivered from the precise angle. The portals used were: for orbit/socket and extra-ocular spread, frontal with a lead shield protection for the other eye. For eye involvement alone, with a posterior tumor, lens sparing temporal and for anterior and large tumors a frontal portal was utilized. Most of the children receiving EBRT had Stage IV or above stage retinoblastoma. EBRT was in all cases combined with anti-metastatic chemotherapy (six cycles of adjuvant chemotherapy with vincristine, carboplatin and etoposide). The patients who had undergone enucleation at our hospital or seen before EBRT (for the other eye evaluation under anesthesia) were fitted with an ocular prosthesis. The minimum follow-up period included in this study was 6 months and a maximum of 10 years. The complications seen in all the patients were listed. The follow-up regimen was altered in patients depending on the complications seen and the status of the other eye.

\section{Results}

Total number of $\mathrm{Rb}$ patients seen during the study period from 2003 to 2016 was 68. Among them 39 were boys and 29 were girls. Unilateral $\mathrm{Rb}$ was diagnosed in 42 children and Bilateral $\mathrm{Rb}$ was diagnosed in 26 children. Their age ranged from one year to eight years at the time of diagnosis of retinoblastoma. Twenty one patients with Unilateral $\mathrm{Rb}$ and 13 patients with Bilateral $\mathrm{Rb}$ had Reese-Ellsworth Stage IV disease. Out of 68 patients 46 patients received EBRT. These patients were divided into two groups. Group-I consisted of 29 children who received only Unilateral EBRT while Group-II included 17 patients who received bilateral EBRT. Of the 29 in Group-I, 10 patients received EBRT to one eye, while 19 patients had received EBRT for the empty socket after enucleation. In Group-II (bilateral EBRT), 15 children received EBRT to one eye and the other side socket, while two patients had extraocular spread and received EBRT to both eyes. Various complications of EBRT, as observed in Group-I and Group-II are tabulated in Table -1 and Table -2 respectively. 
Facial hypoplasia was seen in nine patients in Group-I and 12 patients in Group-II. Contracted socket was the most common complication observed in both the groups. Contracted socket was seen in 17 patients of Group-Iand 11 patients of Group-II. Ocular surface abnormalities, radiation retinopathy, cataract, nasolacrimal duct stenosis, orbital cellulitis and optic neuritis were some other complications seen in these patients. For all the patients, minimum follow-up period documented was 6 months and maximum followup period noted was 10 years with an average follow up period of 4.6 years. None of our patients developed any second neoplasm during this follow up period.

Table - 1 Complications seen in Group-I

\begin{tabular}{|l|c|c|}
\hline Type of complication & $\begin{array}{c}\text { Patients with } \\
\text { only socket } \\
\text { radiotherapy }\end{array}$ & $\begin{array}{c}\text { Patients with } \\
\text { one eye } \\
\text { radiotherapy }\end{array}$ \\
\hline Facial hypoplasia & 9 & - \\
\hline Fornix shortening only & $\begin{array}{c}6(4 \text { with } \\
\text { prosthesis) }\end{array}$ & - \\
\hline $\begin{array}{l}\text { Contracted socket - mild } \\
\text { (I-III) }\end{array}$ & $\begin{array}{c}10(7 \text { with } \\
\text { prosthesis) }\end{array}$ & - \\
\hline $\begin{array}{l}\text { Contracted socket - severe } \\
\text { (IV) }\end{array}$ & $\begin{array}{c}\text { (none with } \\
\text { prosthesis) }\end{array}$ & - \\
\hline $\begin{array}{l}\text { Orbital cellulites } \\
\text { upper lid) }\end{array}$ & - \\
\hline Nasolacrimal Duct stenosis & 1 & - \\
\hline $\begin{array}{l}\text { Ocular } \\
\text { abnormalities }\end{array}$ & 4 & 6 \\
\hline Deep keratitis & - & 2 \\
\hline Cataract & - & 2 \\
\hline Radiation retinopathy & - & 4 \\
\hline Optic neuritis & - & 1 \\
\hline Other neoplasms & None & None \\
\hline
\end{tabular}

Table - 2 Complications seen in group II

\begin{tabular}{|l|c|c|}
\hline Type of complication & $\begin{array}{c}\text { Patients with } \\
\text { socket and } \\
\text { other eye } \\
\text { radiotherapy }\end{array}$ & $\begin{array}{c}\text { Patients with both } \\
\text { eye radiotherapy, } \\
\text { with extra ocular } \\
\text { spread }\end{array}$ \\
\hline Facial hypoplasia & 12 & - \\
\hline Fornix shortening only & $\begin{array}{c}3(2 \text { with } \\
\text { prosthesis })\end{array}$ & - \\
\hline $\begin{array}{l}\text { Contracted socket - mild } \\
\text { (I-III) }\end{array}$ & $\begin{array}{c}6(4 \text { with } \\
\text { prosthesis })\end{array}$ & - \\
\hline $\begin{array}{l}\text { Contracted socket }- \text { severe } \\
\text { (IV) }\end{array}$ & $\begin{array}{c}5(2 \text { with } \\
\text { prosthesis })\end{array}$ & - \\
\hline Orbital cellulitis & 3 & - \\
\hline Nasolacrimal Duct stenosis & 1 & 1 \\
\hline $\begin{array}{l}\text { Ocular } \\
\text { abnormalities }\end{array}$ & 12 & - \\
\hline Deep keratitis & -- & 1 \\
\hline Cataract & 1 & \\
\hline Radiation retinopathy & 4 & None \\
\hline Optic neuritis & 1 & \\
\hline Other neoplasms & None & \\
\hline
\end{tabular}

\section{Discussion}

EBRT is now avoided as first modality of treatment for Retinoblastoma because of its complications. Facial hypoplasia and contracted socket both have cosmetic implications and socket reconstruction is difficult in severe degrees of contracture. This is well documented in literature ${ }^{[5,6]}$ and is also highlighted in our study. Out of the 17 patients of Group-I who had contracted socket, 10 patients did not have a conformer / prosthesis put in after primary enucleation. These patients were found to have a greater degree of socket contraction. Similarly in group-II, out of the 11 patients of contracted socket, 5 patients did not have a conformer / prosthesis put in after enucleation. Socket contracture causes difficulty in fitting the prosthesis later. Cases of fornix shortening and mild cases of socket contracture were treated surgically for socket reconstruction with buccal mucosal grafting and amniotic membrane grafting.

Ocular surface abnormalities and dry eye symptoms are documented in literature ${ }^{[7,9]}$ and were also noted in our study. They resolved with the standard treatment of lubricating eye drops and ointments, but kept on recurring on discontinuation of treatment.

Abramson et al have reported ocular complications following initial EBRT in $52.4 \%$ of the retinoblastoma eyes, the most common ocular complication being cataract. ${ }^{[8]}$ But in our group of patients, radiation cataract was seen only in 2 patients each of Group-I and Group-II. Since we do not have all the technical details of EBRT, we are unable to explain this difference in occurrence. The frequency of development of radiation retinopathy was less in our study: as seen in 4 patients of Group-I and 4 patients of Group-II. The same being reported by Chan et al ${ }^{[9]}$ and Fontanesi et al ${ }^{[10]}$.

Orbital cellulitis was seen in 4 patients of Group-I and 3 patients of Group-II, which is not observed, in any other studies. One patient each, of Group-I and Group-II were found to have suspicious lesion at the optic nerve stump in the socket on CT scan. 
All the patients with cellulitis responded well to systemic antibiotics.

The induction of second cancer is reported in many studies after radiation therapy. ${ }^{[3,4,8]}$ But none of our patients did develop any other malignancy as of date. Probably they need to be followed up for longer time to know the chances of development of second malignancy.

\section{Conclusion}

As EBRT is still being used for treating the late stage of $\mathrm{Rb}$, in poor Indian patients, awareness of complications of EBRT is worthwhile. Keeping in mind the complications after EBRT, it is always preferable to start other modalities of treatment for $\mathrm{Rb}$, instead of EBRT. As noted, socket and orbit contraction is less in patients with conformer / prosthesis put in after primary enucleation, it would be prudent for all patients to be fitted with ocular prosthesis prior to EBRT. It is worthwhile trying to surgically enlarge the socket only in mild cases of socket contraction. Late stages of socket contraction are best treated by spectacle prosthesis. Though EBRT is associated with many complications as seen in this study, their timely detection and management can offer a better quality of life to retinoblastoma survivors.

\section{References}

1. Daniel M. Albert, Joan W. Miller, et al. Albert Jackobiec's Principles and practice of Ophthalmology Vol 4; $3^{\text {rd }}$ edition; Saunders Elsevier,2008.

2. Murphee AL, Samuel MA, Harbour JW, et al. Retina Vol 1; 4th edition; Ryan Stephen J; Elsevier Mosby, 2006.

3. Abramson DH, Ellsworth RM, Kitchin FD, Tung G: Second nonocular tumours in retinoblastoma survivors. Are they radiation induced? Ophthalmology 1984; 91:1351-1355.
4. Save SJ, Grosniklaus, Someran AO. Malignant myoepithelioma after radiation for retinoblastoma. Am J Ophthalmol 115;181:1993.

5. Sue C.K, Gang Chen, James F, et al. Orbital development in long term survivors of $R b . \quad \mathrm{J}$ ofClin Oncology 1997;15:1183-9.

6. Imhof SM, Mourits MP, Hofman P et al. Quantification of orbital and mid-facial growth retardation after megavoltage EBRT in children with retinoblastoma. Ophthalmology 1996;103:263.

7. Zeynel A. Karcioaeglu. Orbital tumors: Diagnosis and treatment. Springer 2005:403.

8. Abramson DH, Beaverson KL, Chang ST, Dunkel IJ, McCormick B. Outcome following initial external beam radiotherapy in patients with ReeseEllsworth group Vb retinoblastoma. Arch Ophthalmol. 2004;122:1316-1323.

9. Chan MP, Hungerford JL, Kingston JE, Plowman PN. Salvage external beam radiotherapy after failed primary chemotherapy for bilateral retinoblastoma: rate of eye and vision preservation. $\mathrm{Br}$ J Ophthalmol. 2009 Jul; 93(7):891-4.

10. Fontanesi JPratt CBHustu HOCoffey DKun LEMeyer D. Use of irradiation for therapy of retinoblastoma in children more than1 year old: the St. Jude Children's Research Hospital experience and review of literature. Med Pediatr Oncol. 1995;24321- 326. 